\title{
Editorial
}

\section{Developmental Neuropsychology: Learning Disabilities Assessment and Remediation}

\author{
Janna Glozman*
}

Psychology Department. Moscow State University. Russia

\section{INTRODUCTION}

The problem of difficulties at school throughout the world attracts much attention of psychologists, educators and physicians, because of a significant increase in the number of learning disable pupils [1-3]. The goal of a psychologist is not only and not so much to adapt child to school process, but to reveal the causes of child's difficulties, weak components in his mental development and to determine strategies and methods for their development. This requires neuropsychological skills. Neuropsychological assessment defines a "target" for psycho-pedagogical intervention.

The issue includes international contributions on the problem of learning disabilities, their mechanisms and causes as well as theoretical foundations and methods of their remediation. Among them: [4] Glozman \& Sofia Konina (Russia) and by Sergey Kiselev (Russia); neuropsychological analysis of executive functions (papers

*Address correspondence to this author at the Psychology Department, Moscow State University, named after M.V. Lomonosov, Moscow, Russia; Tel: +08-499-1971755; E-mail: glozman@mail.ru by Bozydar Kaczmarek \& Katarzyna Markiewicz (Poland), by Irina Shevchenko \& Janna Glozman (Russia) and by Natalia Cadavid-Ruiz \& Pablo del Río (Columbia - Spain); and the problem of child-parents relationship (papers by Carla Anauate (Brazil) and by Lubov' Vinnicova (Russia).

The importance of early neuropsychological diagnosis of child's mental functioning to prevent and timely remediate learning disabilities is underlined, as well as the need to study them, as a combination of biological, pedagogical and social factors interacting in each case of learning disable child.

\section{REFERENCES}

[1] Sapir SG, Nitzburg AC, Eds. Children with learning problems. N.Y 1973.

[2] Hynd GW, Obrzut JE. School neuropsychology. J Sch Psychol 1981; 19: 45-50.

[3] Mikadze YV. Developmental neuropsychology. - Saint Petersburg: Peter 2008. (In Russian).

[4] Glozman JM. Develop neuropsychol. London - New York: Psychology- Taylor and Francis group, Press 2013.

(C) Janna Glozman; Licensee Bentham Open.

This is an open access article licensed under the terms of the Creative Commons Attribution Non-Commercial License (http://creativecommons.org/licenses/by$\mathrm{nc} / 3.0 /)$, which permits unrestricted, non-commercial use, distribution and reproduction in any medium, provided the work is properly cited. 